\title{
Why Can Russia "Divide and Rule" Central and Eastern Europe in Energy Policy?
}

\author{
BERTA Szilárd
}

\begin{abstract}
The strategic challenge of the dependence of Central European countries in terms of hydrocarbon import, specifically natural gas, has not been resolved in the past 25 years. Despite repeated calls for joint action - developing common policies, designing joint frameworks, supporting the launch of major European energy in-frastructure projects together - 25 years after the change of regime period the region still stands vulnerable to Russian economic penetration and political influ-ence stemming from our large-scale dependence on Russian gas import. The paper investigates the roots and causes of this deficiency in order to answer the question: "Why and how can Russia still 'Divide and Rule' Central-Eastern Europe in energy policy?" Since we have witnessed the failure of the Nabucco and Southern Stream pipeline projects in recent years, facing the current challenges of the Ukraine crisis, making transit unpredictable, and perceiving a certain dissent among the Visegrád Four $(V 4)^{2}$ in this regard, the paper is to identify the particular interests and negotiation techniques of the parties in order to explain the reasons of failure.
\end{abstract} Keywords: European Union, Visegrád Four, Russian Federation, Energy, Diver- sification, Russian Influence

\section{Introduction}

The European Union is one of the biggest energy consumers in the world, but despite its growing consumption, the territory of most EU member states is generally poor in hydrocar- bon resources, making it also one of the biggest energy importers of the world. A significant ratio of the import comes from the Russian Federation. However, since the gas crises of 2006 and 2009 the Russian supply has become unpredictable and owing to the current Ukrainian crisis the trust amongst member countries of the European Union and Russia is a point of contention. In my paper, I focus on a particular grouping within the EU, the Visegrád coun- tries in Central Europe, namely the Czech Republic, Hungary, Poland and Slovakia as they are primary consumers of Russian energy resources (natural gas). The countries' industry and citizens heavily rely on Russian hydrocarbons, because lacking their own natural resources and relying on existing pipelines built during the Cold War, all four countries cover much of their consumption via the Russian import. From the Russian point of view, both the European Union and the Visegrád countries within are significant trading partners, but due to the gas

1 National University of Public Service, Budapest, Hungary, e-mail: berta.szilard0926@gmail.com

2 Its a regional co-operation amongst Slovakia, Czech Republic, Poland and Hungary. The organization has been established after the collapse of the Soviet Union in order to facilitate their joining towards the European Union as well as NATO. 
debates with and the distrust towards Ukraine, the EU has grown inclined to diversify its hydrocarbon import.

During the past decade some initiatives have been launched in order to reduce the de- pendence both on Russian resources and on Ukrainian transit. Owing to the unsuccessful initiatives, the Visegrád countries must resolve the problem, having to diversify their mar- ket in a common policy framework. These countries recognized that they have to answer a problem in a regional framework, and the most promising one among these has become the North-South Gas Corridor, which could provide a solution for easing Russian dependence. The initiative of the gas corridor was launched in 2010 during the Visegrád Energy Summit in Budapest. Not only the Visegrád countries, but also Romania and Croatia have joined the endeavour to develop the North-South Gas Corridor connecting both the Baltic Sea region and the Adriatic region via interconnectors running through Central Europe, creating alterna- tive gas supply routes for peoples and economies in the region, independent of Russian gas and Ukrainian transit.

But the diversification efforts will not easily succeed due to the multifaceted Russian ties that influence the European market in many ways. Due to crafting bilateral agreements and the presence of Russian ventures often occupying strategic positions in Central and Eastern European countries, Moscow is able to impose countermeasures against European initiatives, blocking coherent and effective regional cooperation. The paper investigates the roots and causes of this deficiency in order to answer the question: "Why and how can Russia still

'Divide and Rule' Central-Eastern Europe in energy policy?" Since we have witnessed the failure of the Nabucco and Southern Stream pipeline projects in recent years, facing the cur- rent challenges of the Ukraine crisis, making transit unpredictable, and perceiving a certain dissent among the V4 in this regard, the following subchapters will examine and identify the particular interests of the parties in order to explain the reasons of failure.

\section{The Energy-Dependence of the European Union and Central European Countries}

Regarding its geo-economic position, the European Union greatly suffers from the lack of energy resources, specifically hydrocarbons, such as crude oil and natural gas. Therefore, the primary aim of the European Union is to provide adequate access to such resources essential for its 28 member countries' economies as well as to European citizens. Due to its enhanced industrial capacity and developed economies the European Union has become one of the biggest energy consumers in the world, and its energy consumption also shows growing ten- dencies. Thus, having top consumption levels and inadequate resources to cover this, Europe is one of the biggest energy importers.

In case of hydrocarbons, the European Union is the third gas and second crude oil con- sumer in the world. The import of crude oil is tremendous, even higher than that of the United States: approximately 66.2 million tons of crude oil is imported annually. Moreover, the EU is the first gas importer in the world: in 2013, 397.1 billion cubic meters (bcm) of gas was imported via pipelines, ${ }^{3}$ out of which 162.4 bcm, 40.89 per cent was imported from the Russian Federation. [4] Besides Russia, Norway is the second biggest gas exporter to the EU

3 Besides imports via pipelines, the European Union imported 50 billion bcm gas through LNG (liquified natural gas) ports. The biggest trade partners were Qatar (23.4 billion bcm) and Algeria (13.5 billion bcm). 
with $102.4 \mathrm{bcm}$ annual imports (25.79 per cent). Algeria is also a significant partner, import- ing $24.8 \mathrm{bcm}$ of gas (6.25 per cent of all gas imports). We can also observe import trends in historical terms: in 1990, the (then) European Community consisted of 12 member countries and the rate of natural gas consumption was 293.3 bcm annually. By 2008, when consump- tion reached the highest level, the EU had 25 member countries, making up an overall consumption of $482.9 \mathrm{bcm}$. After 2008, European gas consumption began to decrease only as a consequence of the ensuing economic crisis. [4]

Central and Eastern European countries represent a particularly important case in Europe for their gas consumption patterns. After the collapse of the Soviet Union, Central Europe- an countries had a chance to advance on the path of Euro-Atlantic integration and join the European Union. This step also created new challenges both to the European Union and to the Central European countries. Energy policy was a particular issue in mind, because the hydrocarbon import dependence of the newly joining countries was even higher than that of the EU-15. [7] Around the time of the 2004 EU-enlargement, the EU-15 imported $41.7 \%$ of their natural gas, while Central European countries had $30 \%$ higher dependence on gas imports. Regarding crude oil imports, the gap between the EU-15 and Central European countries was $10 \%$, with $76.8 \%$ of oil consumption covered through import in the EU-15 and

$87.7 \%$ of consumption covered via imports in Central Europe. [5]

As the European Union was enlarged and 10 new members joined in 2004, including all Visegrád countries (the Czech Republic, Hungary, Poland and Slovakia), they were soon fol- lowed by Romania and Bulgaria in 2007 and finally Croatia in 2013, and their consumption patterns have also influenced EU energy policies. The new members' energy consumption developed along an increasing trend due to their growing economic output. [5] From 1994, the gas consumption of respective Visegrád countries had increased until 2006-2009, fol- lowed by gradual decline due to the economic crisis and the Russian-Ukrainian gas conflicts. According to 2013 data, the gas consumption of the Visegrád countries was $39.1 \mathrm{bcm}$, of which $28 \mathrm{bcm}(71 \%)$ was imported from the Russian Federation. $9.6 \mathrm{bcm}$ natural gas was imported by Poland, $8.4 \mathrm{bcm}$ by the Czech Republic, Slovakia imported $5.3 \mathrm{bcm}$ and 5.9 bcm gas was imported by Hungary. [4]

Table 1. The gas consumption of the Visegrád Countries compared to EU-15 until accession. (Sources: BP, Eurogas, EIA, [4] [5] [13] [14])

\begin{tabular}{|c|c|c|c|c|c|}
\hline Consumption (bcm) & EU-15 & Czech-Republic & Hungary & Poland & Slovakia \\
\hline 1995 & 286.8 & 7.3 & 10.2 & 10.0 & 5.7 \\
\hline 1996 & 340.8 & 8.4 & 11.4 & 10.5 & 6.2 \\
\hline 1997 & 339.0 & 8.5 & 10.8 & 10.5 & 6.3 \\
\hline 1998 & 352.6 & 8.5 & 10.9 & 10.6 & 6.4 \\
\hline 1999 & 366.8 & 8.6 & 11 & 10.3 & 6.4 \\
\hline 2000 & 376.4 & 8.3 & 10.7 & 11.1 & 6.5 \\
\hline 2001 & 385.0 & 8.9 & 11.9 & 11.5 & 6.9 \\
\hline 2002 & 385.0 & 8.7 & 11.8 & 11.2 & 6.5 \\
\hline 2003 & 403.2 & 8.7 & 13.2 & 12.5 & 6.3 \\
\hline 2004 & 415.1 & 9.1 & 13.1 & 13.5 & 6.1 \\
\hline
\end{tabular}




\section{The Russian "Energy Weapon"}

The Russian Federation is rich in energy resources: notwithstanding, the country's coal and uranium production is remarkable as well as its natural gas and crude oil production. Howev- er, for the purposes of this paper the latter ones are of special concern as Russia has proven to be actively using these for pursuing her geopolitical and geo-economic interests within the European Union in her relation towards single Central European EU member countries. This is often referred to as Russia's “energy weapon”. In this subchapter a brief assessment of Russian capabilities in terms of oil and gas is provided. [12]

In terms of crude oil, in 2012, the Russian Federation was the third most significant pro- ducer in the world after Saudi-Arabia and the United States. In the Eurasian region, Russia's territories have the most significant oil fields, even though only $6 \%$ of the world's proven oil reserves are controlled by Moscow. According to 2012 data, 10.5 million barrels of oil were produced daily, out of which 7 million barrels were exported. [5]

Russian (previously Soviet) oil industry became internationally meaningful in the 1960 s, when the most significant Western Siberian reserves had been explored. From that time,

16 million tons of crude oil was exported to Western European countries. [46] During the Cold War, especially in the 1970s crude oil played a more significant role than today, be- cause heavy industry consumed excessive amounts. [21]

In 1964, the oil pipeline "Dhruzba" (Friendship) was constructed, bringing crude oil to the Soviet satellite countries.

This pipe- line has provided oil from Russian resources to Hungary, Czechoslovakia, Poland and East Germany as well, and Dhruzba plays an important role even today. Soviet crude oil produc- tion and export peaked in 1987 at 624 million tons, from which Russia itself produced 570 million tons. After the collapse of the Soviet Union, the production continuously dwindled until 1996, when only 300 million tons crude oil was produced. But from 2000, when

Vlad- imir Putin came to power, Russian oil production started to increase. By 2013, 531.4 million tons of oil was produced, putting Russia in second place after Saudi Arabia in the world. [4] In terms of natural gas, the Russian

Federation is the second biggest producer, and pro- duction could further be increased if the reserves under the Arctic would open up. According to 2013 data, Russia has the largest proven natural gas reserves in the world, approximately 1.688 trillion cubic feet. [47]

The role of natural gas in economic production has also increased throughout the past decades, along with the Soviet Union's, then Russia's economic influence in this field. Pro- duction has expanded due to the exploration of new energy reserves in the 1970 and 1980s. The two largest fields, Urengoy ${ }^{4}$ and Yamburg ${ }^{5}$ had been discovered then. Export to Western Europe was booming during the 1970s. [20] The transit through Ukraine increased enor- mously, from 3.4 $\mathrm{bcm}$ to $26 \mathrm{bcm}$ and in the following decade this trend further continued. The Soviet export peaked at $109 \mathrm{bcm}$ from which $63 \mathrm{bcm}$ was exported to Western Europe, making the region the most significant consumer of Soviet gas.

In 2013 the Russian Federation produced $604.8 \mathrm{bcm}$ of gas, of which $211.3 \mathrm{bcm}$ gas was exported by Moscow $162.4 \mathrm{bcm}$ to the European Union. [4]

48.099 trillion cubic meter; 286 trillion cubic feet

54.81 trillion cubic meter; 170 trillion cubic feet 


\section{The Role of Ukraine as a Transit Country}

Ukraine has not always been suffering from the lack of energy resources. During the 1960s the country was an important hydrocarbon exporter to Europe. Production peaked in 1972 when the country produced 14.4 million tons of crude oil, but afterwards production slowed down due to the exhaustion of the fields, further exacerbated by the collapse of the Soviet Union. [23] Nowadays Ukraine is a net crude oil importer, with 14.4 million tons of oil imported in 2011 for example. [33] Even though production seems to be significant, it does not cover the demand, thus Naftogaz has to import $57 \%$ of their demands from the Russian Federation. [23]

In terms of natural gas the situation is similar, because Ukraine in the 1970s used to be a determining exporter, supplying gas to Poland, Czechoslovakia and even to Austria. Produc- tion peaked at approximately $68.7 \mathrm{bcm}$ in 1975 , but due to the exhaustion of the gas fields this amount rapidly decreased soon afterwards. Nowadays Ukraine is able to produce $20 \mathrm{bcm}$ of natural gas, but it is enough to cover only $33 \%$ of homeland demand because the country is one of the biggest gas consumers, thus also importers in the world. The relationship between Russia and Ukraine greatly affects the energy supply, as the Russian state-owned company, Gazprom is its biggest supplier. [40] Even though Ukraine is one of the largest gas importers in the world, recent years have witnessed a reduction in gas consumption for various reasons: due to rising prices, the 2008 economic recession and the notably decreased export of heavy industrial products. For comparison: in 2005 consumption was $76.4 \mathrm{bcm}$, but this amount decreased to $59.3 \mathrm{bcm}$ by 2008. In 2012 (before the current crisis heavily afflicting the prime regions of economic production in Eastern Ukraine) this was only 54.9 bcm. [23]

From the Russian point of view Ukraine is not only a significant trading partner, but also a key transit country, moreover, it is a geopolitical pillar, which bonds Russia with the Euro- pean Union. [15] In 1991, after the collapse of the Soviet Union, Ukraine inherited 38,600 kilometres of the pipeline system connecting Russian production sites to European markets, making Ukraine the most important transit country in the region. Before the subsequent cri- ses 142.5 bcm of natural gas was imported via this pipeline system to the EU annually. There are two pre-eminent gas pipelines crossing the territory of Ukraine, and both the Bratstvo (Brotherhood) and the Soyuz (Union) [1] pipelines play an important role in the European supply.

On the one hand, the "Bratstvo" (Brotherhood) pipeline is the longest pipeline reaching the European market. The 4,451 kilometer long pipeline breaks in two arms after leaving Ukraine: one of them transports gas to Slovakia, Hungary, Austria, Italy and the Balkans Peninsula, while the other arm supplies the Czech Republic, Germany, Switzerland and France. [52] This channel covers 20\% of European gas consumption, and $80 \%$ of the Rus- sian export. "Brotherhood" is able to transport 95-120 bcm of gas annually. [15] Soyuz, on the other hand, is 2,675 kilometers long, linking natural gas networks in Central Asia with Europe and supplies additional volumes to Central Europe, able to transport 26-32 bcm of gas annually. [28]

The significance of Ukraine is given by the fact that in the past, as much as $80 \%$ of Rus- sian natural gas exports to Europe transited Ukraine. This number has fallen to 50\%-60\% since the North Stream pipeline, a direct link between Russia and Germany under the Baltic 
Sea, was built in 2011. Even in 2014 about 16\% (3.0 trillion cubic feet) of the total natural gas consumed in Europe passed through Ukraine's pipeline network, as estimated by EIA. ${ }^{6}$

We can see a decreasing trend, further put under pressure by the Eastern Ukraine crisis, but the transit role of the country is likely to remain further on as well. However, the safety and predictability of supply have repeatedly been threatened, both in 2006 and in 2009 during the Russo-Ukrainian gas disputes, which heavily impacted Central European interest as well.

\section{The 2006 and 2009 Gas Disputes between Russia and Ukraine}

The relationship between Russia and Ukraine affects energy supply of both the European Union at large and the Visegrád countries in particular. There have been several notable occasions when due to the deteriorating bilateral relations between these countries sustain- able gas supplies to the Visegrád countries became endangered. [9] During such debates, the following issues are determining: (1) Ukraine cannot pay for the import; (2) loans are either not provided or are not paid back; (3) the European transits are illegally tapped; (4) Russia cuts the flow of gas, because Ukraine is not able to pay for it. Because of recurring problems, tensions have escalated into serious crises in 2006 and 2009. [37]

As the antecedent of the 2006 gas dispute, the relations between Russia and Ukraine deteriorated as a consequence of the 2004 Ukrainian "Orange Revolution", triggering dis- satisfaction in Moscow. In 2005 Russia raised repeated claims that Ukraine was not paying for gas and was diverting gas bound from Russia to the European Union, for domestic needs. The dispute peaked on 1 January, 2006 when Russia cut off supply. The cut off affected gas supplies to European countries that depended on Russian natural gas: Hungary received $40 \%$ less gas than normally, while Austria, Slovakia and Romania received one third less. The crisis also had an impact on Polish supplies, providing 14\% less resources, and on France (25-30\% decrease in supplies), while Bosnia and Herzegovina, Croatia and Serbia tempo- rarily lost all their gas imports. On 4 January, 2006 a preliminary agreement was reached, setting gas prices at 95 USD per 1,000 cubic metres and raising the transit tariff from 1.09

USD to 1.60 USD per 1,000 cubic meters per $100 \mathrm{~km}$, and soon the supply was restored. [40] In 2009 another crisis developed when Ukrainian internal politics confronted Moscow's will. In 2007 Ukrainian president Viktor Janukovics and the Gazprom set an agreement on gas prices, raising it to 179.5 USD per $1000 \mathrm{bcm}$. In 2008, when Julia Timosenko came into power as prime minister, Russia wanted to seal a new contract with Kiev. The negotiation between

Timosenko, Juscsenko and Gazprom stalled, therefore the Russian partner began to decrease the gas supply. [40] On January 6, 2009 Russian export to Ukraine was at a really low level, furthermore, export from Ukraine to Western European countries was totally halt- ed. [34] The next day Gazprom totally cut export via Ukraine. Eventually, negotiations met success and Gazprom determined the price of gas on the basis of the 2008 agreement. After 13 days, Russia re-opened gas taps and the gas supply was restored. [40]

Central European countries greatly suffered from the effects of the crisis. Poland, whose primary source of energy is coal, suffered less during these 13 days, because the 33\% loss from Ukraine could be replaced via the Jamal gas pipeline, crossing Belarus. The Czech Re- public, whose gas production was $98 \%$ dependent on the Russian supply, could rely on the

$616 \%$ of Natural Gas Consumed in Europe Flows Through Ukraine 
country's gas storages, storing enough natural gas for cover 40 days' domestic consumption. On the other hand, Prague also increased its Norwegian import by $8 \%$ via the "Netra" pipe- line system. Slovakia was affected extremely during the 2009 crisis, because the country was

98\% dependent on Russian import. During the conflict, Slovakia was able to substitute the

Russian gas thanks to additional inflow from the Czech Republic and gas storages. Still, about

1 billion euros were lost during these 13 days, because the country was not able to transit gas to Western Europe. Hungary was also sensitively affected, because $82 \%$ of the country's gas consumption came from the Russian Federation. Because of the well-developed underground gas storage facilities, the country was able to accumulate enough gas supply for 40 days. It is also worth noting that during the crisis, when countries of the Western Balkans suffered critical outage, Hungary was able to transport gas to Serbia as well. As a direct consequence of the two crises, both the European Union and the Visegrád countries have lost trust towards Ukraine as a transit country and grew more sceptical towards Russia as a reliable supplier, therefore they began to foster new initiatives of diversification. [42]

\section{Diversification: a Dream or Reality?}

As a result of the repeated crises, the Visegrád countries recognized that if they wanted to se- cure gas supplies, it could be done through the diversification of suppliers and supply routes, for which they had to collaborate effectively in order to better pursue their interest. Having to respond to these conflicts, Central European countries have found a solution to decrease their dependency on Russia. In February 2010, 11 countries $^{7}$ from Central and Southeast Europe organized a joint Energy Summit in Budapest in order to discuss the possibilities of diversification for their markets through strengthening cooperation and integrating their net- works with each other. The endeavour was supported by the European Committee, Romania, Bulgaria and Croatia as well. [8]

Beyond negotiating regional cooperation in 2010, these countries had already been seek- ing alternative solutions to lessen the Russian and Ukrainian influence. Such initiatives were developing alternative gas pipelines that would circumvent Ukraine and also possibly pro- vide the transport of non-Russian gas from Central Asia.

\section{"Nabucco"}

The first of such initiatives was the Nabucco gas pipeline, announced already in 2002. First of all, the Austrian companies OMV and the Turkish partner BOTAS were the initiators of the project, because that time the Visegrád countries, as well as Romania, Bulgaria, Slovenia and Croatia were not members of the European Union. [31] According to the plans, the 3.300 kilometer pipeline would have been able to transport $20 \mathrm{bcm}$ of natural gas annually. The main partner would have been Azerbaijan, but as Baku would not have been able to cover the whole export, Turkmenistan, Iran and the Kurdish territories in Northern Iraq also would have provided resources. The European countries wanted to mitigate the Russian influence and this was the reason why they supported the initiative worth 12 billion Euros. The system would have consisted of three phases: [22]

7 The Visegrád 4 countries, Austria, Croatia, Slovenia, Bosnia and Hercegovina, Serbia, Romania and Bulgaria. 
- The first phase would have been finished in 2014 , and would have been able to supply $8 \mathrm{bcm}$ of natural gas annually.

- The second phase would have been finished by 2018 and could have transported $15 \mathrm{bcm} /$ year.

- Finally, the third phase of the construction would have been finished by 2022 , making it possible to provide altogether $30 \mathrm{bcm}$ of gas transport.

Due to the 2006 Russo-Ukrainian gas crisis the Nabucco project enjoyed broad support on behalf of the European Union. Despite this fact, initially Hungary was against the con- struction, because former Hungarian prime minister, Gyurcsány Ferenc provided support to the Blue Stream [16] gas pipeline instead. ${ }^{8}$ Eventually, from the beginnig of 2007 the Hungarian point of view changed ${ }^{9}$ and Hungary became the most prominent supporter of the initiative. Besides Hungary, Austria, Slovakia, the Czech Republic, Poland, Germany, Roma- nia and Bulgaria favoured the Nabucco project. On 13 July, 2009, a multilateral agreement was adopted and signed by the shareholders and the Turkmen president Berdimuhamedow. In spite of this, due to changing geopolitical realities and altered regional plans the develop- ment of the Nabucco pipeline was finally rejected by OMV,${ }^{10}$ citing that the countries rather preferred the Trans-Adriatic Pipeline. We can also assume that the European Union did not support the project so much because of the relatively high development costs and the rela- tively low transport capacity. [6]

\section{"Southern Stream"}

The initiative to build Southern Stream as an alternative gas supply route circumventing Ukraine was framed in 2007, when Paolo Scaroni, the president of ENI ${ }^{11}$ and Alexander Medvedev, the vice president of Gazprom signed an agreement for project development. [18] The project was built on two main pillars. First of all, the aim of the pipeline (similarly to the Nabucco gas pipeline) was to increase energy security in Europe, but compared to the Nabucco project, here the Russian Federation would have been a stakeholder via state-owned Gazprom, casting doubt on endeavours of easing Russian dependence. As a second pillar, it was a priority to bypass primarily Ukraine, and also Belorus, which was also a Russian inter- est having seen Ukraine's ambivalent stand as transit country. [10]

The project was an individual initiative with a length of 2,506 kilometers, out of which 930 kilometers would run under the Black Sea, binding Russia directly with the European Union through the newly joining member state, Bulgaria. Between 2008 and 2011, negoti- ations continued and other investors entered the project with the support of other regional countries, like Bulgaria, Hungary, Serbia, Slovenia, Slovakia and the Czech Republic, whose energy supply then mostly depended on Gazprom. Not only these countries but Austria could also find a lucrative opportunity, because the end of Southern Stream would have been in Baumgarten. (Poland was neutral in this question as the Jamal pipeline provided it natural gas via Belarus.) The development of the pipeline system would have cost approximately 21.5

8 The Blue Stream pipeline is 1213 kilometers long, with 396 kilometers passing under the Black Sea. The pipeline provides direct link between Russia and Turkey. In 2014, it was able to transport 16 billion cubic meters of natural gas, but Gazprom wants to increase this capacity.

9 Because Russia agreed to build gas storage facilities in Austria rather than in Hungary

10 Österreichische Mineralölverwaltung - Austrian Mineral Oil Administration

11 Ente Nazionale Idrocarburi - National Hydrocarbons Authority 
billion USD, but half the price of the construction would have been paid by Moscow, who would have been a $50 \%$ stakeholder in the pipeline. [29]

In 2013, when Nabucco was finally rejected, Southern Stream got the green light. Despite the negotiations, the 2013 Ukrainian crisis affected negatively both EU-Russian relations and the Southern Stream project itself. Even in 2014 the parties seemed to be confident, except for some negative voices that remained skeptical about the implementation. As the Ukraine conflict evolved further and political and economic relations between the Europe- an Union and Russia significantly deteriorated, and economic sanctions were introduced, the Southern Stream project was abolished from the agenda by Vladimir Putin, and instead plans for building a new Turkish-Russian gas pipeline were announced to replace Southern Stream. Thus Southern Stream ended up unrealized similarly to Nabucco while the diversifi- cation attempts of Central European countries have remained unresolved. [36]

\section{"Trans-Adriatic Pipeline" (TAP)}

The Trans-Adriatic gas pipeline is an old initiative in a new setup, planned to be finished by 2019. Similarly to Nabucco, the pipeline will come from Azerbaijan across Turkey, Greece, and Albania, ending in Italy, because the Mediterranean country (especially its industrially developed Northern region) could become another European gas transit hub. The project is supported by Norwegian Statoil, Swiss Axpo, and German E.ON-Ruhrgas. [30] This project is an alternative energy route, which could replace - to a lesser extent - the Russian import as the pipeline would be able to transport $10 \mathrm{bcm}$ of gas. But if further expanded, it could export up to $20 \mathrm{bcm}$ of natural gas to the European market. Construction might start from 2016, and the 3500 kilometers long pipeline would join the TransAnatolian Natural Gas Pipeline (TANAP), leading towards Greece. This initiative is not determining from the Visegrád coun- tries' point of view, it would be more significant for Southern and Western European coun- tries. The construction of the TAP pipeline would cost 2 billion USD, which would require less investment than Nabucco or Southern Stream. [44]

For Central European countries, the outcome of the decade-long negotiation in this regard is unfavorable because the region will not gain a new direct access-route for gas, nor would these countries gain other resources than Russian in the near future. Despite the planned construction of TAP, the gas diversification aim of Central European countries will not be fulfilled. 
Table 2. A comparison of the planned pipelines towards the European Union in recent years. (Sources: Natural Gas Europe [29] [30], Gazprom [18])

\begin{tabular}{|c|c|c|c|}
\hline & Nabucco & South Stream & $\begin{array}{l}\text { Trans-Adriatic } \\
\text { Pipeline (TAP) }\end{array}$ \\
\hline $\begin{array}{l}\text { Negotiation Started / } \\
\text { Failed } \\
\text { (year) }\end{array}$ & $2002 / 2013$ & $2006 / 2014$ & 2006 \\
\hline $\begin{array}{l}\text { Planned Length } \\
(\mathrm{km})\end{array}$ & 3300 & 2500 & 900 \\
\hline $\begin{array}{l}\text { Planned Capacity } \\
\text { (bcm) }\end{array}$ & $20-31$ & 63 & $10-20$ \\
\hline Source of gas & Azerbaijan* & $\begin{array}{l}\text { The Russian } \\
\text { Federation }\end{array}$ & Azerbaijan \\
\hline $\begin{array}{l}\text { Vulnerability of the } \\
\text { project }\end{array}$ & $\begin{array}{c}\text { Lack of EU support, } \\
\text { South- Stream }\end{array}$ & $\begin{array}{c}\text { EU Third Energy } \\
\text { Package, } \\
\text { Russia rejected }\end{array}$ & In Process \\
\hline $\begin{array}{l}\text { Supporters / } \\
\text { Investors }\end{array}$ & $\begin{array}{c}\text { Turkey (Botas), } \\
\text { Bulgaria (Bulgarian } \\
\text { Energy Holding), } \\
\text { Hungary (MOL), } \\
\text { Austria (OMW), } \\
\text { Germany (RWE), } \\
\text { Romania (Trans- } \\
\text { gaz), } \\
\text { Poland (PGNiG) }\end{array}$ & $\begin{array}{c}\text { Greece, } \\
\text { Bulgaria, } \\
\text { Serbia, } \\
\text { Romania, } \\
\text { Hungary, } \\
\text { Slovakia }\end{array}$ & $\begin{array}{c}\text { Azerbaijan } \\
\text { (SOCAR), } \\
\text { Greece (DEPA) } \\
\text { Albania } \\
\text { Italy (ENI) } \\
\text { Switzerland (Fluxys } \\
\text { Enagás and Axpo) } \\
\text { Norway( Statoil) } \\
\text { United Kingdom } \\
\text { (BP) }\end{array}$ \\
\hline Opponents & Russian Federation & $\begin{array}{c}\text { Poland, Baltic } \\
\text { States, Italy (ENI), } \\
\text { France (EDF) }\end{array}$ & $\mathrm{n} / \mathrm{a}$ \\
\hline $\begin{array}{l}\text { Estimated Price } \\
\text { (Euros) }\end{array}$ & 7.9 billion & $10-16$ billion & 2 billion \\
\hline
\end{tabular}

*Opportunities: Iraq, Iran, Turkmenistan

\section{Vulnerabilities and Opportunities for the Visegrád countries, Croatia and Romania}

As we have seen, Central and Southeast European countries have not been able to resolve diversification, thus the Visegrád countries chose to advance their cooperation in a regional framework. Thus, the North-South Gas Corridor has become a priority among Central Euro- pean countries, because in this way the countries could diversify their supply independent of Russian resources as well as Ukrainian transit. [19] The plan of the gas corridor stretching from Poland to Croatia was first mentioned in February 2010 at the Budapest Energy Sum- mit. Drawing on the lessons learnt from the 2009 gas conflict, the countries signed a deal to 
implement the project in 2011. Even when the Nabucco and the Southern Stream projects still seemed to be viable, the countries have always supported the idea of developing a North- South gas corridor, which would offer a new alternative for Central European gas supply. Despite that the corridor requires regional cooperation, the countries individually have to develop their gas transportation systems themselves, which I am going to briefly introduce in the following.

\section{Poland}

Polish gas consumption has increased in the previous years from $13.3 \mathrm{bcm}$ to $18.1 \mathrm{bcm}$, but this amount would grow further in the forthcoming years. [50] After the 2009 gas dispute, Central European countries have taken some innovative steps to decrease their Russian de- pendence through implementing the North-South gas corridor initiative. From Poland's point of view the Swinoujsce $\mathrm{LNG}^{12}$ terminal plays a crucial role. The terminal will be able to re- ceive 5 bcm of gas that might further be extended to $7.5 \mathrm{bcm}$ when construction will be com- pleted. [42] According to the bilateral agreement signed, Poland's biggest LNG import [38] partner would be Qatar the Middle-Eastern country, which will be able to supply $1.5 \mathrm{bcm}$ of natural gas annually from 2014 on for a 20-year period. [2] Another important step towards improving the country's secure supply is to extend its underground gas storage system. Gas storage facilities in Poland are able to store $1.8 \mathrm{bcm}$ natural gas, but the Polish national gas company, PGNIG is planning to develop the capacity to $2.8 \mathrm{bcm}$. Nowadays the amount stored would be enough to supply the country for 39 days, but after further developments the storages will be able to store gas necessary for covering the domestic consumption for

55 days. [43]

\section{The Czech Republic}

The Czech Republic, as other Central European countries as well imports a significant amount of natural gas from Russia and Central Asia via pipelines running through Ukraine and Slovakia. [48] Due to the lack of hydrocarbon resources domestic gas production is real- ly low in the country that can cover only $2 \%$ of the consumption. The main source of import is Russia, which seemed to be a reliable source until the 2006 and 2009 gas crises. [53] When Russia or Ukraine occasionally cut the supply, Prague had to collaborate with other partners. Therefore, Norway increased its export to the Czech Republic via the OPAL and Gazella pipeline systems to $30 \mathrm{bcm}$ per year, thus Norway providing for $22 \%$ of the Czech consump- tion, significantly diversifying the country's supply. [39] Moreover, the Czech underground storages also play an important role, because there are 8 storages able to stockpile $3.5 \mathrm{bcm}$ of natural gas, enough for up to 50 days. [32] Thus, it seems that the country has been able to decrease Russian dependence and became one of the well-diversified countries in the region, setting a good example for Central European countries. [25]

12 Liquefied Natural Gas 


\section{Slovakia}

Slovakia's domestic gas consumption is $5.3 \mathrm{bcm}, 97 \%$ of which is imported from the Russian Federation, because the country is able to produce only 150 million cubic meters of gas annu- ally. [51] (Based on available studies, this amount will further rapidly shrink in the following years, making up only 90 million cubic meters.) [42] Slovakia is not only an end-consum- er, but also an important transit country in a somewhat similar position as Ukraine, piping towards Western Europe and the Baumgarten gas hub in Austria. Situated in the heart of Central Europe, Slovakia's import can be diversified through building interconnectors to the North and South. [53] Such interconnectors could provide 17 million cubic meters of gas daily, therefore a new pipeline between Velky-Krtiš (Nagykürtös) and the Hungarian city Vecsés would offer this alternative. The pipeline is planned to be able to transport $5 \mathrm{bcm}$ of gas to Bratislava once the construction would be finished by 2015 . The underground gas storage system of the country is also essential, because it could store $3.12 \mathrm{bcm}$ of natural gas, an amount enough to provide for domestic consumption for 30 days. [43]

\section{Hungary}

Hungary is quite poor in energy resources; able to produce approximately $2 \mathrm{bcm}$ of natural gas annually, but this amount is rapidly shrinking due to the exploitation of gas fields. [42] Ener- gy consumption patterns represent a declining tendency, primarily due to the recent economic recession: between 2005 and 2012 consumption decreased from $15 \mathrm{bcm}$ to 10.2 bcm. [49] Still, 76\% of the gas consumption is covered by import from Russia via Ukraine. [41] In order to improve sustainable supply, Hungary has also begun to build interconnectors, for example the Szeged-Arad gas pipeline that can transport $1.8 \mathrm{bcm}$ of gas annually. [53] From the Hungarian point of view gas storages plays an outstanding role, constructed already be- fore the 2009 crisis and then continued. The capacity of the storages were $1.2 \mathrm{bcm}$ before the crisis, but after the facilities had been enlarged, they made up altogether $5.43 \mathrm{bcm}$, keeping supplies necessary to cover the consumption of 40-45 days. [43]

Table 3. An overview of gas resources and dependency of the Visegrád Countries.

(Sources: [4] [5])

\begin{tabular}{|l|c|c|c|c|}
\hline & Poland & $\begin{array}{c}\text { Czech } \\
\text { Republic }\end{array}$ & Hungary & Slovakia \\
\hline Reserves* & 100 & $\mathrm{n} / \mathrm{a}$ & $\mathrm{n} / \mathrm{a}$ & $\mathrm{n} / \mathrm{a}$ \\
\hline Consumption** & 16.7 & 8.4 & 8.6 & 5.4 \\
\hline Production & 6.1 & 0.2 & 2.2 & 0.1 \\
\hline Import dependency & $65.8 \%$ & $97.6 \%$ & $78.2 \%$ & $97.2 \%$ \\
\hline Import from Russia & 9.6 & 7.2 & 5.9 & 5.3 \\
\hline
\end{tabular}

*: billion cubic metre $(\mathrm{bcm}) ; * *$ bcm annually 


\section{Croatia}

Croatia became a main pillar of the North-South gas corridor after joining the European Union in 2013. It is noteworthy that the country is not suffering from the lack of energy re- sources and is not dependent on Russian import, because natural gas is not the main energy source in Croatia's energy mix. Natural gas makes up only $28 \%$ of the whole energy mix, moreover, out of the $3 \mathrm{bcm}$ of annual gas consumption, $1.9-2.5 \mathrm{bcm}(70 \%)$ is produced domestically. These reserves will only be sufficient for 10 more years, the remaining quan- tity is imported by the Italian ENI company. [35] The country is an important pillar of the North-South gas corridor because of its LNG terminal on the island of Krk, which would be the Southern end of the corridor, also serving as the second entry point for supplies. [43] The terminal will be able to receive $5 \mathrm{bcm}$ liquefied natural gas annually from Qatar in the next 25 years from 2017, once construction will be finished. The terminal will be able to receive $10 \mathrm{bcm}$ of natural gas and Zagreb could upgrade it to $15 \mathrm{bcm}$ later on. Croatia's contribution to the regional diversification initiatives is the interconnector built between Városfölde and Slobodnica together with Hungary, able to transport $6.5 \mathrm{bcm}$ of natural gas annually. (Currently only $1.5 \mathrm{bcm}$ of gas is flowing through the pipeline from South to North.)

\section{Romania}

Romania itself has significant natural gas resources, therefore the country is less dependent on import in general, or on Russian import via Ukrainian transit in particular. From a con- sumption of $13.48 \mathrm{bcm}, 10.63 \mathrm{bcm}$ of gas is produced domestically. [43] From the remaining

$3 \mathrm{bcm}$ that needs to be imported, Russia only covers 720 million cubic meters, or $24 \%$ of the Romanian consumption. Therefore, the Russian influence is not so strong on Romania than on the other Central European countries in terms of energy policies. Also in terms of storage facilities, the country has a well-developed system: 8 underground storages can keep $2.8 \mathrm{bcm}$ of gas, but in the next years these might further expand by an additional $2.1 \mathrm{bcm}$.

Besides, the country framed multiple initiatives to diversify its market. The interconnec- tor pipeline between Arad and Szeged, completed in 2010, is able to transport $4.4 \mathrm{bcm}$ be- tween Hungary and Romania, even though a significant weakness of the pipeline is that there is no reverse flow. [55] The Iasi-Ungheni pipeline was accomplished in 2014, connecting Romania with Moldova, able to supply $1.5 \mathrm{bcm}$ of gas, which can cover $30 \%$ of the Molda- vian consumption. A new diversification initiative that might become a meaningful tool for the whole region was announced in 2010: the Azerbaijan-Georgia-Romania Interconnector (AGRI). It would provide natural gas from the Caspian Sea region primarily to Romania and to the European Union. The pipeline would come from Azerbaijan across Georgia, then liquefied gas would cross the Black Sea to Romania through LNG ports and through inter-connectors the pipeline might end in Hungary. The pipeline is to be constructed by 2024 and it should transport $8 \mathrm{bcm}$ of gas. [54]

In sum, we have seen that for the Visegrád countries the relationship with the Russian Federation in terms of energy policies is significant, if not primarily determining, Russia being the most important gas (and oil) exporter for them. Building on recent diversification initiatives two other countries, Croatia and Romania need to play a role in developing the necessary interconnectors, thus making it possible to bring in LNG from North, South or 
Southeast to Central Europe and enable countries to support each other in case of Russian and

Ukrainian break in supplies through these.

At the same time the past decade has witnessed the failure of two major European pipe- line initiatives, Nabucco and South Stream, showing that the consensus over shared interests is vulnerable. In the next section I will take a look at Russian ties in the region in the indus- trial, banking and military sectors, arguing that Moscow was able to continuously increase her economic influence in Central European countries through which occasionally was able to exert political influence as well, dividing European consensus that would have been neces- sary to develop long-lasting strategic solutions in the field of energy policy.

\section{Russian Economic Ties in the Visegrád Countries}

The countries in the European Union represent different stands towards the Russian Federa- tion; some of them are more reluctant and try to ease and lessen their relations with Moscow, especially to decrease dependences. A good example from the Visegrád countries is Poland. On the other hand, there are some who have developed more complex, relatively deep eco- nomic ties, often dependences on Russia. These represent different degrees in the particular cases of the other three Visegrád countries: the Czech Republic, Slovakia and Hungary. If we seek an answer to the question how can Russia indirectly influence economic and political decisions of strategic importance in these countries, we need to take a look at economic rela- tions not only in terms of the energy sector, but other sectors as well. [24]

\section{Poland}

The relationship between Poland and Russia has not changed drastically during the past 25 years: despite the provisional rapprochement in $2010,{ }^{13}$ relations have remained rather cool. Because of this, the rate of the Russian investments in the country is relatively low, reaching only $1 \%$ of total foreign direct investment (FDI) in Poland. (Notwithstanding that Cyprus

- the biggest Russian offshore partner - invested funds in Poland, providing $3.55 \%$ of total FDI.)

Russian investments are rather significant in the energy sector: Russian companies have expanded their role in the oil sector since 1996; currently the Russian oil venture Lukoil op- erates 116 filling stations. Owing to the negative Polish attitude and the effects of the 2008 economic crisis, the company abandoned its expansion efforts. Russian influence is also no- ticeable in the gas sector as assessed earlier, because of the Russian gas import via the Jamal gas pipeline. [24] The joint venture responsible for the Russian natural gas supply, EuRoPol Gaz is also partly under Russian control as $48-48 \%$ of the company's shares are owned by Polish state oil and gas company, PGNiG and Russian stateowned company Gazprom. (The remaining 4\% are being held by other investors.) As in April 2013 EuRoPol Gaz and Gaz- prom signed the Memorandum of Understanding about the construction of the Yamal-Euro- pa II gas pipeline, the company is to retain a significant role in the coming years as well. [17]

13 It was the consequence of the crash of the Polish Air Force Tu-154 near Smolensk on 10 April 2010, killing

96 people on board, including senior members of the Polish political, military and clerical elite. Russian political and societal reactions and cooperation during the investigation of the crash offered the chance of rapprochement, later thwarted by the ensuing crisis in Ukraine. 


\section{The Czech Republic}

Even though the relationship between the Czech Republic and Russia was assessed as "prag- matic and cold" before the current crisis, one could observe extensive Russian economic expansion as Moscow was striving to strengthen her influence step by step. A good exam- ple of extending Russian influence both directly and indirectly is the RussianCzech Mixed Chamber of Commerce which provides support for Russian investors in the country. The organization is headed by Vladimir Ermakov, the general director of the biggest Czech gas venture, VEMEX, whose majority shares (51\%) are owned by Gazprom. [24]

We could also observe a Russian expansion in the banking sector: the First Czech-Rus- sian Bank (FCRB) was established in 1996. [3] The bank opened a new branch in Slovakia in 2008 and in Prague in 2009. Not only FCRB, but also Russian-owned Sberbank plays an important role in Central Europe, purchasing Volksbank in 2012.

In the industrial sector, the ChTPZ Group is remarkable, because this is the biggest company dealing with pipes. The company integrated the $\mathrm{MSA}^{14}$ venture, whose director was the 25-year-old son of the Russian energy and industry minister, Viktr Khristenko. In 2006, the personal safety equipment producer Vostok Service purchased the Cerva Export Import a.s. company, which had had meaningful connections to international organizations and indus- trial ventures since 1991. In 2008 and 2009, the purchased company extended continuously and gained influence in several countries: the Czech Republic, Slovakia, Poland, Hungary, Italy and India. Vostok Service is held by Vladimir Golovnev, who was a member of the Russian Duma from 2007 until 2011. Moreover, in 2008 the Ural Mining and Metallurgical Company (UGMK) gained 51\% of the shares from Aircraft Industries, the biggest Czech company in the aircraft industry. The goal of UGMK is to reach a significant position in re- gional air transport, signaled by the development of the L-140 aircraft. The value of Russian investments was 14 million dollars in 2009, increased to 76 million dollars by 2013. In 2014 the remaining $49 \%$ of the company's shares were also purchased by UGMK. From 2004 on the number of the Russian industrial stakeholders in the Czech Republic has increased. The Russian company OMZ (United Heavy Machinery) purchased Skoda Js, Skoda Hute and Skoda Kovárny. In 2010, name of the company was changed to Pilsen Steel and it was sold to the United Group. [45]

Furthermore, Russian involvement became apparent in the energy sector as well. Besides Vemex Company, TVEL Fuel Company is under the control of Rosatom - $49 \%$ of the shares are in the Russian companies' hands. Moreover, Lukoil purchased JET filing stations in 2007 (later sold to Hungarian MOL ${ }^{15}$ in 2014).

In the field of informatics and telecommunications the Russian influence is also notice- able. The Russian company JSC NIIME and Micron established Sitronics Company with a Czech partner STROM Telecom in 2002. In 2005 Sitronics purchased both Kvazar-Micro Ukrainian and Greek Intracom Telecom. In 2012, the Russian-owned AFK Sistema Group purchased the whole Sitronic. Thus, as we have seen, both the scale and complexity of Rus- sian investments have increased in the Czech Republic in the past decade.

14 Manufacturer of industrial valves

15 Magyar Olaj- és Gázipari Részvénytársaság - Hungarian Oil \& Gas Company Plc. 


\section{Slovakia}

Slovakia depends directly on Russian investments primarily in the energy sector. Due to the lack of energy sources, Russian partners play significant roles in the natural gas and crude oil supply. Owing to this hegemony, Moscow is dominant in the field of the natural gas transit. The bilateral strategy of Gazprom of signing long-term agreements with partners has worked in Slovakia as well. [26] The treaty between Gazprom and the Slovak state-owned gas com- pany, SPP (Slovenský Plynárenský Priemysel A.s. - Slovak Gas Industry) was signed in 2009 for twenty years, until 2029. Slovakia remains one of the most important transit coun- tries of the European Union, channeling gas from Ukraine and Belarus towards the Czech Republic, Germany and Austria.

Lukoil plays an important role in Slovakia, purchasing the filling stations of Conoco Phillips. In the banking sector, the Russian Sberbank purchased Volksbank's local branches in 2012. Furthermore, Atomstroyexport plays an important role in the construction of the Mochovce Nuclear Power Plant, strengthening Russian dominance in the nuclear energy sec- tor. Rusatom Overseas, the subsidiary of Rosatom supervises the constructions. Moreover, there are some other Russian investments in Slovakia via offshore partners from Cyprus, the Netherlands and Switzerland. [24]

\section{Hungary}

Hungary has witnessed repeated attempts at extending Russian economic influence in the country in various economic sectors. 2000 was the first time when Gazprom began to expand its interest via offshore ventures. An Irish company, Milford tried to gain the ma- jority of the shares of chemical companies Borsodchem and TVK. ${ }^{16}$ (Despite the efforts, Milford was unable to buy the shares and the companies were purchased by an Austrian stakeholder. Some years later the Hungarian state-owned gas company MOL repurchased the companies.) [11]

Russian influence is also remarkable in the banking sector as in 1996 a Russian investor, Megdet Rakhimkulov entered into Hungarian banking spheres by purchasing $\mathrm{AEB}^{17}$ via Gaz- prombank. $70 \%$ of the AEB shares are used by Gazprombank and Gazprom. Furthermore, Sberbank has become a relatively new competitor by buying local Volksbank branches in 2012. By 2018 Sberbank aims to increase its market presence above 5\%, but had to abandon these ideas as a consequence of current EU sanctions. Still, 9\% of OTP ${ }^{18}$ shares are controlled by Rakhimkulov.

During 2009 and 2011 there was an attempt to increase Russian shares in the energy sec- tor when Austrian OMW sold the $21.2 \%$ of the shares of MOL to Surgutneftegaz. [27] The ambitious Russian investor was stopped in 2011, when the Hungarian Government purchased the shares for 1.88 billion Euros. Due to the failure of Surgutneftegaz, there are no Russian companies with shareholdings in the Visegrád countries' refinery industry.

The greatest debate and controversy was triggered by the agreement on the reconstruction and modernization of the Paks Nuclear Power Plant, signed in 2014. Russian Rosatom had

16 Tiszai Vegyi Kombinát Nyrt. - Tisza Chemical Group Plc.

17 Általános Értékforgalmi Bank - General Banking and Trust Co.

18 Országos Takarékpénztár és Kereskedelmi Bank Nyrt. - National Savings and Commercial Bank Ltd. 
been designated as the major constructor, developing $5^{\text {th }}$ and $6^{\text {th }}$ power plant blocks. In order to finance the project, the Hungarian Government also signed a credit and loan agreement worth 10 billion Euros from Russia, provoking heavy criticism and creating direct economic dependence from Russia. [24]

\section{Conclusions}

The aim of the paper was to offer an assessment in the field of energy policy in Central Europe, focusing especially on the natural gas dependency of the Visegrád countries from Russia in order to identify vulnerabilities and highlight opportunities for these countries. As I have listed above, all countries in Central Europe depend on Russian energy import to varying degrees, moreover, many countries also depend on Ukrainian transit. The gas dis- putes of 2006 and 2009 have shown that such multiple dependences undermine the reliable supply of gas, therefore countries in the region have attempted to streamline their efforts for easing these dependences through diversification in four ways: first, through constructing new pipelines, diversifying the supply of gas from other suppliers than Russia, particularly in Central Asia and the Caspian region; second, through diversifying transit routes to cir- cumvent Ukraine or other countries of concern for instability of unreliability; third, through enhancing their respective gas storage capacities by building additional storage facilities; fourth, through constructing interconnectors along the North - South Gas Corridor in order to facilitate the supply of gas through all countries in Central Europe by importing LNG gas to Poland, Croatia or Romania.

The past years have also shown that the consensus necessary for realizing such regional initiatives is often vulnerable to particular interests or external influence. The failure of the Nabucco and South Stream projects, despite their European support and major stakeholders' participation has shown that opposing or changing Russian interests might prove be hard. Regional cooperation for constructing the still missing interconnectors seems to be a viable option that might at last make Central European gas import largely independent of Russian natural gas - at least in times of need.

A particular vulnerability has also been identified in the paper: direct or indirect Russian economic influence in Central European countries that may influence the Visegrád countries' ability to negotiate freely. The Russian Federation and major Russian companies, such as Gazprom in the energy sector are aware of this fact and try to negotiate with the countries on an individual basis. Russian investors offer different opportunities to partners at different prices - both literally and metaphorically - to strengthen their influence. Above all, Moscow is able to reach his aims via the energy sector, because Russian influence is strongest in this sphere. The state-owned company, Gazprom influences its partners via long-term agree- ments, reduced energy prices or different transport "discounts".

Furthermore, Russia is often able to exploit economic opportunities and strives to widen her influence in other sectors as well. As we have seen in the last part of the paper, Rus- sian companies show a lively presence on the European market, often trying to occupy key positions in strategic sectors, involving the industrial, trading, technological and banking sectors as well. In this way the Russian Federation is able to influence, sometimes even to divide (Central) European unity and consensus, which establishes an asymmetric relationship among the member states of the European Union. The Visegrád countries play an important 
role in this context, because their interests are similar, as well as the Russian influence is significant in these Central European countries. They have to co-operate to counterbalance or even push back unwanted strategic partners. Whenever European unity is divided, Russia is able to expand her interests. If European countries and the European Union want to retain their freedom of movement, they need to cooperate and should speak with one voice.

\section{References}

[1] A BARREL FULL: Soyuz Pipeline. abarrelfull.wikidot.com. http://abarrelfull.wikidot.com/ soyuz-pipeline (downloaded: 3009 2014)

[2] ASCARI, S.: The Gas Target Model for the Visegrad 4 Region. Warsaw: OSW, 2013. http:// aei.pitt.edu/58012/1/raport_04_the-gas-target-model_net_0.pdf (downloaded: 2002 2015) [3] First Czech-Russian Bank.

banki.ru. www.banki.ru/banks/engbanks/bank/?id=5715 (downloaded: 0503 2015) DOI: https://doi.org/10.2139/ssrn.2378830

[4] BRITISH PETROL: Statistical Review of World Energy 2014. $63^{\text {rd }}$ edition. Uckfield: Pureprint Group, 2014. www.bp.com/content/dam/bp/pdf/Energy-economics/statistical- review-2014/BP-statistical-review-of-world-energy2014-full-report.pdf (downloaded: 22 02 2015)

[5] BRITISH PETROL: Statistical Review of World Energy Workbook 2013. www.bp.com/ content/dam/bp/excel/EnergyEconomics/statistical-review-2014/BP-Statistical_Review_of_world_energy_2014_workbook.xlsx, downloaded (02 22 2015) (downloaded: 2202 2015)

[6] CENTRAL EUROPEAN POLICY INSTITUTE: Visegrad's Energy Security after Nabucco. CEPI News, 14 October 2013. www.cepolicy.org/news/visegrads-energy-security-after- nabucco (downloaded: 1002 2015)

[7] CONGRESSIONAL RESEARCH CENTER: Europe's Energy Security: Options and Challenges to Natural Gas Supply Diversification. http://fas.org/sgp/crs/row/R42405.pdf (downloaded: 1502 2015)

[8] KORANYI, D., SPRUDS, A.: Natural Gas and Energy Security in the Visegrad and the Baltic States. Washington, D.C.: Center for Transatlantic Relations, 2011. http://transatlantic. saisjhu.edu/partnerships/Cornerstone\%20Project/cornerstone_project_koranyi_spruds_paper.pdf (downloaded: 1802 2015)

[9] DEÁK A. Gy.: Orosz-ukrán gázháború újra. In. MKI-Tanulmányok, T-2009/3. http://kki.gov.hu/download/9/e9/b0000/Tanulmanyok_2009_03_\%5B\%C3\%BAj_ publik\%C3\%A1ci\%C3\%B3_\%5D.pdf (downloaded: 1502 2015)

[10] DEÁK A. Gy.: Jön! Jön! Jön! - a Déli áramlat. Grotius, 2012. www.grotius.hu/doc/pub/ VELGUJ/2012_86_deak_andras_gyorgy_a_deli_aramlatl.pdf (downloaded: 1702 2015)

[11] DEÁK B.: Nem elöször harcol a Mol osztrákokkal. origo.hu. 2007. július 05. www.origo.hu/ gazdasag/hirek/20070705-molomv-harc-borsodchem-tvk.html (downloaded: 0603 2015) [12] EUROPEAN COUNCIL ON

FOREIGN RELATIONS: European Foreign Policy Scorecard. www.ecfr.eu/scorecard (downloaded: 0503 2015)

[13] EUROGAS: Statistical Report 2013; www.eurogas.org/uploads/media/Eurogas_Statistical_Report_2013.pdf (downloaded: 2802 2015)

[14] EUROGAS: Statistical Report 2014. Brussels: EUROGAS, 2014. www.eurogas.org/ uploads/media/Eurogas_Statistical_Report_2014.pdf (downloaded: 2802 2015) 
BERTA Szilárd: Why Can Russia "Divide and Rule" Central and Eastern Europe in Energy Policy?

[15] EUROPEAN UNION: Ukraine Country File, 2010. http://ec.europa.eu/energy/observatory/ doc/country/2010_04_ukraine.pdf (downloaded: 0110 2014)

[16] GAZPROM: Blue Stream. www.gazprom.com/about/production/projects/pipelines/blue- stream/ (downloaded (03 10 2014)

[17] GAZPROM: Gazprom and EuRoPol GAZ to cooperate under Yamal - Europe-2 gas pipeline project. 5 April 2013. www.gazprom.com/press/news/2013/april/article159672/ (downloaded: 0503 2015)

[18] GAZPROM: South-Stream.www.gazprom.com/about/production/projects/pipelines/south- stream/ (downloaded:15 02 2015)

[19] GAZ-SYSTEM: North-South Gas Corridor. http://en.gaz-system.pl/our-investments/ integration-with-european-gas-tramsmission-system/north-south-gas-corridor/ (downloaded: 1202 2014)

[20] GRACE, J. D., HART, G. F: Urengoy Gas Field - U.S.S.R. West Siberian Basin, Tyumen District. In. Structural Traps III: Tectonic Fold and Fault Traps. Tulsa: The AAPG / Datapages Combined Publications Database, A017 (1990), 309-335. http://archives. datapages.com/data/specpubs/fieldst3/data/a017/a017/0001/0300/0309.htm (downloaded: 07

09 2014)

[21] HISTORY: Energy Crisis (1970s). www.history.com/topics/energy-crisis (downloaded: 09 09 2015)

[22] KOSSE, I. (Ed.): European Integration: Experience of V4 Countries and Ukrainian Reality. Kyiv: Institute For Economic Research And Policy Consulting, 2014. www.ier.com.ua/files// publications/Books/IER_EuroInteg_en_final.pdf (downloaded: 1502 2015)

[23] INTERNATIONAL ENERGY AGENCY: Ukraine 2012. Paris: IEA, 2012. www.iea.org/ publications/freepublications/publication/Ukraine2012_free.pdf (downloaded: 2309 2014) [24] KALOTAY

K., ÉLTETÖ A., SASS M., WEINER Cs.: Russian capital in the Visegrád countries. Budapest: MTA Institute of World Economics, 2014. www.vki.hu/news/ news_788.html (downloaded: 0203 2015) DOI: https://doi.org/10.2139/ssrn.2535997

[25] KAŁAN, D.: Window to the West: The Importance of the Czech Natural Gas Market for V4. Bulletin, 25478 (2013), 1-2. www.pism.pl/files/?id_plik=13150 (downloaded: 2702 2015) [26] KAŁAN, D.:

East of Centre: Can the Visegrad Group Speak with One Voice on Eastern Policy? Policy Paper, 53 (2013), 1-10. www.pism.pl/files/?id_plik=13017 (downloaded: 2702 2015)

[27] MNO: Botránnyá fajult a Mol részvényeinek felvásárlása. http://mno.hu/migr/botrannya_ fajult_a_mol_reszvenyeinek_felvasarlasa-303009 (downloaded: 0603 2015)

[28] NAFTOGAZ OF UKRAINE: "Naftogaz of Ukraine" and Ferrostaal ( Germany) have signed the Memorandum of understanding on modernization of gas-pumping equipment for "Soyuz" gas pipeline. 02 July 2012. www.naftogaz.com/www/3/nakweben. nsf/0/1D0B7A87954D7717C2257A9C00484B48 (downloaded: 3009 2014)

[29] NATURAL GAS EUROPE: South Stream. (Homepage). www.naturalgaseurope.com/ category/pipelines/south-stream-pipeline (downloaded: 1502 2015)

[30] NATURAL GAS EUROPE: Trans Adriatic Pipeline (TAP). (Homepage). www.naturalgaseurope.com/category/pipelines/trans-adriatic-pipeline (downloaded: 1502 2015)

[31] NÉMETH B.: A kisállamok szerepe a Nabucco gázvezetékben. Nemzet és Biztonság, 07 (2009), 54-62. www.nemzetesbiztonsag.hu/cikkek/nemeth_bence-a_kisallamok_\$ARRAPS_\$14)ab(2095)gazvezetekben.pdf (downloaded: 0802 2015) 
[32] NOSKO, A., LANG, P.:: Lesson from Prague: How the Czech Republic has Enhanced Its Energy Security. European Dialogue, 26 July 2010. www.eurodialogue.eu/Lessons-from- Prague-How-the-Czech-Republic-Has-Enhanced-ItsEnergy-Security- (downloaded: 2802

2015)

[33] O'GRADY, B.: Weekly Geopolitical Report. Saint Louis: Confluence Invest Management, 2014. www.raymondjames.com/markpalios/pdfs/140609_weeklygeo.pdf (downloaded: 12 10 2014)

[34] RUSSIAN ANALYTICAL DIGEST: The Russian-Ukrainian gas conflict. Zurich: Center for Security Studies, 2009. www.css.ethz.ch/publications/pdfs/RAD-53.pdf (downloaded: 12 05 2015)

[35] SADECKI, A.: The prospects for Croatia's co-operation with the Visegrad Group. OSW Commentary No. 116. In. Archive of European Integration. OSW Commentary. 06 December 2014. http://aei.pitt.edu/57929/ (downloaded: 1002 2015)

[36] South-Stream. www.south-stream-offshore.com (downloaded:15 02 2015)

[37] STERN, J.: The Russian-Ukrainian gas crisis of January 2006. Oxford: Oxford Institute for Energy Studies, 2006. www.oxfordenergy.org/wpcms/wp-content/uploads/2011/01/Jan2006RussiaUkraineGasCrisis-JonathanStern.pdf (downloaded:12 05 2014)

[38] SZALAI, P.: Gas in Central Europe: From Russia to Qatar and back. Bratislava: DCE, 2012. http://visegradrevue.eu/gas-in-central-europe-from-russia-to-qatar-and-back/ (downloaded: 1502 2015)

[39] SZIRKÓ A.: A visegrádi négyek az Európai Unió és Oroszország energetikai kapcsolataiban. Budapest: Corvinus Egyetem, 2010. www.academia.edu/4587812/A_ visegr\%C3\%A1di_n\%C3\%A9gyek_az_Eur\%C3\%B3pai_Uni\%C3\%B3_\%C3\%A9s_ Oroszorsz\%C3\%A1g_energetikai_kapcsolataiban (downloaded: 2502 2015)

[40] PIRANI, S.: Ukraine's gas sector. Oxford: Oxford Institute for Energy Studies, 2007. www.oxfordenergy.org/wpcms/wp-content/uploads/2010/11/NG21-UkrainesGasSector- SimonPirani-2007.pdf (downloaded: 1205 2014)

[41] RÁCZ A.: Divided stands the Visegrad? The V4 have been united towards the Ukraine crisis but remain split concerning Russia. FIIA Briefing Paper, 06 (2014), 1-8. www.fiia.fi/en/ publication/428/divided_stands_the_visegrad/ (downloaded: 24 02 2015)

[42] KOVÁCS P., SZCZERSKI, K., BINHACK, P., FARKAS M., JAROŠ, J., KOŁACZKOWSKI, M., RUSZEL, M., SZLAGOWSKI, P., SZOLNOKI E., ŠEVCE, P., ALBRYCHT, I.: Energy Security of the V4 countries. How do energy relations change in Europe? Krakow: The Kosciuszko Institute, 2011. www.pssi.cz/download/docs/117_energy- security-ofthe-v4-countries.pdf (downloaded: 1702 2015)

[43] ĆWIEK-KARPOWICZ, J., KAŁAN, D. (Eds.): North-South Gas Corridor Geopolitical Breakthrough in Central Europe. Warsaw: The Polish Institute of International Affairs, 2013. www.pism.pl/files/?id_plik=15698 (downloaded: 1902 2015)

[44] Trans Adriatic Pipeline. (Homepage). www.tap-ag.com/ (downloaded:15 02 2015) [45] United Group.

(Homepage). www.untdgroup.com/ (downloaded: 0503 2015)

[46] US ENERGY INFORMATION ADMINISTRATION: Petroleum Chronology of Events 1970-2000. Washington, D.C.: eia, 2002. www.eia.gov/pub/oil_gas/petroleum/analysis_ publications/chronology/petroleumchronology2000.htm\#T_8_(downloaded: 0809 2014) [47] US ENERGY

INFORMATION ADMINISTRATION: Russia. Washington, D.C.: eia, 2015. www.eia.gov/beta/international/analysis.cfm?iso=RUS (downloaded: 3008 2015) 
BERTA Szilárd: Why Can Russia "Divide and Rule" Central and Eastern Europe in Energy Policy?

[48] US ENERGY INFORMATION ADMINISTRATION: Czech Republic. Washington, D.C.: eia, s.d. www.eia.gov/countries/country-data.cfm?fips=EZ (downloaded: 1503 2015)

[49] US ENERGY INFORMATION ADMINISTRATION: Hungary. Washington, D.C.: eia, s.d. www.eia.gov/beta/international/?fips=HU (downloaded: 1503 2015)

[50] US ENERGY INFORMATION ADMINISTRATION: Poland. Washington, D.C.: eia, s.d. www.eia.gov/beta/international/?fips=pl (downloaded: 1503 2015)

[51] US ENERGY INFORMATION ADMINISTRATION: Slovakia. Washington, D.C.: eia, s.d. www.eia.gov/beta/international/?fips=lo (downloaded: 1503 2015)

[52] VILÁGGAZDASÁG ONLINE: Felrobbant a testvériség gázvezeték Ukrajnában. vg.hu/vallalatok/energia, 2014. 06. 17. www.vg.hu/vallalatok/energia/felrobbant-a-testveriseg- gazvezetek-ukrajnaban-foto-429497 (downloaded: 0110 2014)

[53] INTERNATIONAL ENERGY AGENCY: Energy Supply Security: Emergency Response of IEA Countries - 2014 Edition. Paris: IEA, 2014. www.iea.org/publications/freepublications/ publication/energy-supply-security-theemergency-response-of-iea-countries-2014.html (downloaded: 1002 2015)

[54] AGRI. (Homepage). www.agrilng.com/Home/EUProjectOfCommonInterest (downloaded: $10032015)$

[55] PIPELINES INTERNATIONAL: AGRI gas pipeline feasibility study underway. 27 September 2012. http://pipelinesinternational.com/news/agri_gas_pipeline_feasibility_ study_underway/077942/(downloaded: 1003 2015) 